\title{
System management and labour relations transformation in relation with talented, healthy and sportsman staff
}

\author{
ALEXEY A. CHISTYAKOV 1,2 , NIKOLAY A. MASHKIN ${ }^{3}$, IZIDA I. ISHMURADOVA ${ }^{4}$, GULNARA F. RUCHKINA ${ }^{5}$, \\ NIGINA S. BABIEVA6 ${ }^{6}$, ALBINA R. SHAIDULLINA ${ }^{7}$ \\ ${ }^{1}$ Department of Criminal Law, Criminal Procedure and Criminalistics, Peoples' Friendship University of Russia, Moscow, Russian Federation \\ 2Department of Criminal Law, Academy of the Federal Penal Service of Russia, Ryazan, Russian Federation \\ ${ }^{3}$ Department of State and Legal Disciplines, Plekhanov Russian University of Economics, Moscow, Russian Federation \\ ${ }^{4}$ Department of Business Informatics and Mathematical Methods in Economics, Kazan (Volga Region) Federal University, Kazan, Russian \\ Federation \\ ${ }^{5}$ Department of Legal Regulation of Economic Activity, Financial University under the Government of the Russian Federation (Financial \\ University), Moscow, Russian Federation \\ ${ }^{6}$ Department of Nursing Activities and Social Work, The Sechenov First Moscow State Medical University, Moscow, Russian Federation \\ ${ }^{7}$ Department of Foreign Languages, Almetyevsk State Oil Institute, Almetyevsk, Russian Federation
}

\begin{abstract}
The relevance of this article is to study new principles of work and interaction with staff. Currently, there is a transformation of labour relations. All these forces employers to actively search for talented employees inside and outside their companies, and then ensure their development and worthy use in solving priority business tasks. There is a need for system personnel management. The aim of the research is to explore ways to manage successful effective employees in information technology companies as an approach to human resources management. Research methods: as a research method, the questionnaire method was used to analyse the organization of the employee management system in Russian companies related to information technology. Research results: the article examines the experience of applying the concept of personnel management in IT companies. The novelty and originality of the research lies in the fact that for the first time the system of personnel management in the field of information technology was studied. It is shown that being an actively developing field related to information technologies - it is constantly in need of personnel. It is determined that not all employees of information technology companies are highly qualified, which may be due to the high demand for labour resources. It is revealed that the activities carried out in almost all companies include staff motivation and the formation of a remuneration system (compensation and incentives); recruitment; evaluation of company personnel; training management. It is determined that the need for changes may be due to such factors as changing the company's work profile, the arrival of a new boss, setting new tasks for the HR Department. It is revealed that representatives of companies see the need to make changes in the company's motivation in the remuneration system, training and development of personnel, career management and performance management, creating an effective team and evaluating personnel. It is shown that the system of motivation of ordinary employees and successful employees does not differ critically in most companies. They are motivated by additional payments (bonuses) and gratitude for the work done. It is determined that the motivating factors are corporate sports, individual types of incentives, additional payments for work experience. It is shown that the main motives for work from the point of view of employees are decent and guaranteed financial remuneration, the presence of certain job responsibilities and clear company policy, as well as the presence of diversity in work and interest in it. Practical significance: the data Obtained in this work can be used in marketing, management, Economics, personnel management, management psychology.
\end{abstract}

Keywords: Labour relations; Talented staff; Sportsman staff; Motivation; Information technology companies; Management system.

\section{Cite this article as:}

Chistyakov, A.A., Mashkin, N.A., Ishmuradova, I.I., Ruchkina, G.F., Babieva, N.S., \& Shaidullina, A.R. (2021). System management and labour relations transformation in relation with talented, healthy and sportsman staff. Journal of Human Sport and Exercise, 16(3proc), S1323-S1329. https://doi.org/10.14198/ihse.2021.16.Proc3.47

Corresponding author. Department of Criminal Law, Criminal Procedure and Criminalistics, Peoples' Friendship University of Russia, Moscow, Russian Federation.

E-mail: sauber60@yandex.ru

Abstract submitted to: Winter Conferences of Sports Science. Costa Blanca Sports Science Events, 22-23 March 2021. Alicante, Spain.

JOURNAL OF HUMAN SPORT \& EXERCISE ISSN 1988-5202.

(c) Faculty of Education. University of Alicante.

doi:10.14198/jhse.2021.16.Proc3.47 


\section{INTRODUCTION}

Currently, there is a transformation of labour relations; in many cases, developing crisis processes are associated with inefficient state regulation of social, economic and labour relations (Artyukhova \& Kozlova, 2009; Shkatulla, 1997; Volovskaya, 2001; Castels, 2000). In the conditions of weak trade unions and lack of proper state control over the implementation of labour legislation, employees were disenfranchised in organizations (Kuzmin, 1993; Alder, 2003; Dryakhlov \& Kupriyanov, 2002; Korobeynikov, 2001). Today, the state focuses on financial and monetary policy, ignoring the problems associated with the restructuring of social and labour relations. This situation is very different from the Western one, where the regulation of social and labour relations is the main part of state control in the field of labour. Much attention to social and labour relations in the West is also paid by organizations-owners of companies and people involved in personnel management. In Russia, large companies are undergoing active changes: they are rethinking their positions in the market, revising business processes and organizational structures. Innovations are being introduced in various areas of the company's life (Khitsenko, 2000; Belyatsky, 2001; Sotnikov, 2001; Khanmurzina et al., 2020; Shebunyaeva, 2011). At present, the gap between the segments of the population in earnings and living standards is becoming more and more obvious, which, in turn, increasingly leads to a swaying of crisis phenomena in social and labour relations; reduces productivity and motivation for work among low-paid workers; reduces economic growth in various industries, and so on (Lukashevich, 1998; Moll, 2003; Chernomorenko, 1997; Stolyarov, 2001).

In order to gain new competitive advantages, enterprises begin to deal with soft factors that affect the organization: the development of managerial competencies, updating the corporate culture, and maintaining employee satisfaction. The first step is the formation of a personnel reserve, and then-the introduction of a management system for capable employees (Strebkov, 2012; Dombrovsky, 2002; Yegorshin, 1999; Tsabolova et al., 2019; Kibanov, 2002). Transformation of society and labour dictates new conditions for human development and the formation of a new type of employee (Cherdymova et al., 2017). In modern society, a person capable of transformation and independent development of skills and abilities is becoming in demand (Zavyalova \& Denisov, 2008; Bat'kovsky \& Popos, 1999; Klimov, 1999).

\section{MATERIALS AND METHODS}

The problem field of research is the organization of a talent management system in information technology companies. The object of the study was the heads of Russian companies related to information technology. The study had the following objectives: to assess the status of Russian companies related to information technologies; to assess the needs for change, to define prerequisites for the establishment of a control system by capable employees; to explore the understanding of the control system by capable employees; to assess the constituent elements of a control system by capable employees: (strategy for talent management; recruiting and nurturing talent; and talent development; career management and performance of talents; the system of motivation of employees.

Questions, which are suggested in the questionnaire:

How would you describe this stage of your company's development?

What are the challenges facing your company in the field of personnel management? 
How would you evaluate your organization's current performance against the indicators planned at the beginning of the year? (high performance: we exceed the stated plan figures in all spheres of our activity; rather, high performance: operate in accordance with plan indicators and slightly exceed the values in some areas; average performance: in some ways we rather surpass the performance plan, than lagging behind; rather poor performance: the company is behind schedule in some areas; low performance: the company's position has sharply deteriorated in some areas of activity).

How do you search for capable employees for your company?

What is your forecast for the organization's development in the next six months?

What were the main changes for your organization in the previous year? (rapid growth of the company; expansion of the company by entering new markets; rapid or significant changes in the market or in external conditions; merger of the company with another; change in the company's strategy; the need to use innovations; threats to competition; a new management team; obsolescence of the product or service we offer; reduced profits; a sharp decline in the industry; there is no key changes for the company occurred).

How do you assess your company's readiness to undergo these changes?

What mechanisms of capable employees' development are used in the company?

What type of training is required for all groups of employees?

What are the current priority areas for development?

What areas require correction or changes? (Staff evaluation; talent development; staff training and development; staff career management; succession planning; staff motivation; Leadership development; remuneration system (compensation and incentives); change management; performance management)

\section{RESULTS}

The study reveals that there are quite serious personnel movements in companies. Most companies ( $56 \%$ of companies) hired about $15 \%$ of employees, $24 \%$ of companies hired slightly less employees - $10 \%$; $13 \%$ of companies said they hired $27 \%$ of employees, and the remaining $7 \%$ of the organization slightly more $-51 \%$. Despite hiring a sufficient number of new employees, organizations have not been without layoffs or reductions. Most companies (51\% of companies) reduced their number of employees by $10 \% ; 32 \%$ of companies did not lay off or reduce employees. More than $25 \%$ of the workforce was reduced in $13 \%$ of companies, and $4 \%$ of organizations reduced the number of their employees by $11 \%$. Companies associated with information technology are characterized by high growth dynamics; active development is associated with a wide demand for products in this industry, so companies are forced to attract a large number of employees. A small number of layoffs may be due to the high level of specialists recruited in the organization.

Some companies (25\%) described themselves as being in growth, entering a new stage of development, offering new products and services, $13 \%$ of companies are at the start and are experiencing the first years of operation, forming a list of services, $13 \%$ of companies said that they were in the period of a new birth, the organization was still in a crisis state, but there were already prerequisites for getting out of it, the rest rated themselves as stable. 
Organizations constantly face changes in their activities, both in the internal environment and in the external one. The majority of companies (56\% of companies), participated in the study often experienced rapid and significant market changes in external conditions and the need of innovation, $13 \%$ of companies as the main changes outlined inner transformation: change the company's strategy and new team leaders. Every fifth company identified such transformations as changes in the cost of resources and the merger of a company with another. Some organizations noted the main changes: rapid growth of the company, expansion by entering new markets, and reduced profits. Some companies noted as changes - threats of competition, obsolescence of the offered products or services, introduction of a large number of goods and services.

Employees are an important resource in the service industry. The level of profitability of the company depends on the qualifications of employees. Today, the need for personnel in most organizations is rather growing ( $67 \%$ of companies), that is, open positions are available in some departments. At the same time, $24 \%$ of companies stated that there was no need for personnel. $56 \%$ of respondents rated the current need for employees in their organizations as growing: there are many open positions. The number of employees of companies associated with information technology is growing, which indicates a growing need for products and services in the field of information technology, high growth potential of the industry and organizations involved in information technology. As for the basis of information technology companies-technical and engineering specialists, the situation is as follows: $56 \%$ of companies have highly qualified specialists, and $42 \%$ of organizations have average qualified specialists. In $2 \%$ of the companies, employees with weak qualifications occupy the positions of technical specialists.

Sales agents in organizations that specialize in the field of information technology have different qualifications. In $25 \%$ of companies, employees with average qualifications occupy this position, in $25 \%$ of companies, employees with weak knowledge and undeveloped skills occupy the position of sales agents, $50 \%$ of organizations, on the contrary, have a high level of competence development in this group of employees. Thus, in most of the companies involved in the study, ordinary employees have average qualifications with the appropriate skills and knowledge. The sphere related to information technologies, as it is actively developing, needs stuff constantly. Not all employees are highly qualified, which may be due to the high demand for labour resources - it is not immediately possible to find many good specialists.

Changes that regularly occur in companies do not frighten the management, which is able to resist them. This fact is most likely related to the management's understanding of the dynamic development of the sphere and the perception of a large number of changes as features of the sphere.

The study participants were asked to determine the importance of the problems that their companies faced in the field of personnel management. In General, these problems are mostly of low significance, which indicates a low importance of personnel for companies associated with information technology, or a high level of system development. The problem associated with the lack of development of new competencies required due to changes in the company or in the market appears as an important problem for $20 \%$ of companies, while for the rest, this problem is considered insignificant and not a priority. The lack of a common culture is perceived as a priority problem by $15 \%$ of respondents, $85 \%$ of respondents do not perceive this problem as important. $15 \%$ of the company probably experienced employee dissatisfaction with salary cuts or layoffs, since this problem is important for them, while for other organizations this problem is not a priority. The lack of performance indicators is a more important problem for companies related to information technology, so for $45 \%$ of organizations this problem is a priority, for $55 \%$ it is less important. The lack of an automated personnel management system is an important problem for $15 \%$ of representatives of information technology 
companies who answer the survey questions. $85 \%$ of respondents did not consider the lack of this system to be a priority problem.

Respondents noted the areas of personnel management that were present in their organizations. The activities that are carried out in almost all companies include staff motivation and the formation of a remuneration system (compensation and incentives) (100\%); recruitment (95\%); evaluation of company personnel, which is also a common activity of HR departments $(90 \%)$; training management is present in $85 \%$ of companies.

Companies, based on established practices and goals, place greater emphasis on certain areas of activity in the field of personnel management. However, the need for changes eventually arises in organizations, which may be caused by such factors as changing the company's work profile, the arrival of a new boss, setting new tasks for the HR Department, etc. Representatives of companies see the need to make changes in the company's motivation in the remuneration system, training and development of personnel, career management and performance management, creating an effective team and evaluating personnel.

\section{DISCUSSION}

It can be concluded that most of the companies associated with information technology are in a stable state or a state of growth. The size of an organization is one of the factors that affect the achievement of company indicators - the larger the organization, the higher the indicators. Large organizations have extensive experience and stability in the market, which is reflected in the performance of their current activities. This trend is typical for information technology companies in General, as information technology is currently one of the most developing areas. Companies associated with information technologies exist in conditions of constant changes, so they are highly adapted to them and are always ready for subsequent transformations.

Companies associated with information technology are growing in numbers, and most organizations have a high need for personnel. There is a relationship between the position held and the level of employees' qualification, so top management and employees at the level of Directors in most companies are highly qualified, and among employees with lower positions, employees with high qualifications are less common. The level of ordinary employees' knowledge, most of whom have average qualifications, also appears mediocre. Engineering and technical specialists in most organizations have a high and medium level of qualification, although among this category of employees in the field of information technology, in order to build highly effective activities, highly qualified employees must prevail. It is possible that due to the high dynamic growth of companies and the need to recruit a large number of employees, the management of organizations are forced to sacrifice the quality of the recruited employees as opposed to the number. The most important problems, according to most companies, are a broken leadership system and the lack or poor development of performance indicators. The problem that none of the respondents perceive as significant is the upcoming retirement of key employees. It is possible that due to the fact that companies are faced with a dynamic pace of work and a large amount of work, management does not have time to devote time to employees and establish a more or less employee management system, so problems arise in this area.

The areas that receive the most attention in information technology companies are staff motivation and remuneration systems. These areas are common in most of the companies participating in the study, and about half of this number of companies consider these areas a priority and feel the need to make changes to them. This may be due to a lack of information about possible areas of personnel management. 


\section{CONCLUSION}

Most companies are working on career planning for employees. Most organizations note that employees talk at least once a year with their direct supervisor (an employee of the HR Department) about what qualities and skills need to be developed in order to become more successful, but not every tenth company participating in the study conducts such work. Only half of companies formalize an oral conversation about talent development into an individual plan for developing the necessary qualities and skills for a particular employee.

The structure of training in the company can be built, or it can be implemented randomly according to the needs of employees or the needs of the company's culture, etc. In most companies, respondents note that attending trainings in their organizations is encouraged by management, while management does not mention the merits of training their successful employees in any way.

Most of the companies participating in the study note that their organization has all the conditions for professional development and study, and everything depends only on the desire of the talent itself. The system of motivation of ordinary employees and successful employees does not differ critically in most companies. In other words, the system of incentives and motivation is the same for all employees.

They are motivated by additional payments (bonuses) and gratitude for the work done. Motivating factors such as internal and external training, recognition of the importance and exclusivity of the employee's work are popular in most companies, and these factors are used for all employees. Almost half of companies use the following motivating factors equally for talented employees and ordinary employees: corporate sports, individual types of incentives, and extra payments for work experience. Based on the respondents' answers, the main motivations for employees' work are decent and guaranteed financial remuneration, the presence of certain job responsibilities and clear company policy, as well as the presence of diversity in work and interest in it.

Thus, the vast majority of companies use the practice of joint discussion of the leader (HR officer) and talents of areas and career paths of successful employees. However, this practice is formalized in an individual employee development plan only in half of the companies, and accordingly, the methods and mechanisms of career management in companies have different degrees of effectiveness. Every employee has a reason to go to work and do it well. All these reasons can be divided into two types: internal reasons, when a person enjoys the very process of their work, and external reasons, when a person benefits from the work they perform.

\section{REFERENCES}

Alder, G. (2003). Marketing of the future: a dialogue of consciousnesses. Communication with consumers in the XXI century. Moscow: Fair Press.

Artyukhova, V.R. \& Kozlova, L.N. (2009). Tasks of the state in regulating the development of the information sphere and the market of information products and services. Bulletin of Orlov State Institute of Economics and Trade, 2, 21-25.

Bat'kovsky, A. \& Popos, S. (1999). Methods of motivation to work and professional growth: on the example of innovative organizations. Problems of management theory and practice, 1, 104-109.

Belyatsky, N.P. (2001). Management: Business career. Moscow: Vysh. Shc.

Castels, M. (2000). Information age: Economy, society and culture. Moscow: open society Institute. 
Cherdymova, E.I., Kuznetcov, V.A., Machnev, V.Y., Solovova, N.V., Sarbaeva, I.Y. \& Masalimova, A.R. (2017). Eco-vocational consciousness formation model of a specialist in modern mega polis. Eurasian Journal of Analytical Chemistry, (12)5b, 521-531. https://doi.org/10.12973/ejac.2017.00187a

Chernomorenko, N.V. (1997). Problems of labor potential effective use. Human resource management: problems and prospects of development: Collection of reports of the international scientific and practical conference. Kiev, 288-295.

Dombrovsky. T. (2002). Charisma. St. Petersburg: Piter.

Dryakhlov, N. \& Kupriyanov, E. (2002). personnel motivation Systems in Western Europe and the USA. Problems of management theory and practice, 2, 83-88.

Yegorshin, A.P. (1999). Personnel Management. N. Novgorod: NIMB.

Khanmurzina, R.R., Cherdymova, E.I., Guryanova, T.Yu., Toriia, R.A., Sukhodolova, E.M., Tararina, L.I. (2020). Computer games influence on everyday social practices of students-gamers. Contemporary Educational Technology, 11(1), 11-23. https://doi.org/10.30935/cet.641753

Khitsenko, V.E. (2000). Evolutionary management. Management in Russia and abroad, 1, 3-12.

Kibanov, A.Ya. (2002). Personnel management of the organization. Moscow: Infra-M.

Klimov, E.A. (1999). Psychology of professional self-determination. R.-na-D.: Phoenix.

Korobeynikov, D. (2001). Life and career: strategic management. Problems of management theory and practice, 6, 77-81.

Kuzmin, S.A. (1993). Market economy and labor. In-t of socio- economic population problems, Moscow: Nauka.

Lukashevich, N. (1998). Business career as a problem of management. Personnel, 1, 46-53.

Moll, E.G. (2003). Managing a Manager's career. Moscow: Peter.

Shebunyaeva, E.A. (2011). Formation of the information technology market in Russia. Socio-economic phenomena and processes, 1, 251-254.

Shkatulla, V. (1997). Humanization of labor relations: a conscious necessity. Man and labor, 3, 57-68.

Sotnikov, S.I. (2001). Career management. Moscow: INFRA-M.

Stolyarov, V.I. (2001). HR management: employee evaluation. Yekaterinburg: Bank of cultural information.

Strebkov, A.Yu. (2012). Management of IT companies: the role of relationship marketing in intraorganizational systems. State, problems and prospects of development of a socially oriented construction complex at the regional level: collection of materials of the II Russian scientific and technical Internet conference. Mikhaylovka: Sebryakovsky branch of Volgograd State Technical University, pp. 393-398.

Tsabolova, O.R., Cherdymova, E.I., Iljin, A.N., Zhukova, M.A., Tsopanova, I.G., Krasnova, L.N., Mashkin, N.A. \& Bugaeva, T.K. (2019). Ecology of psycho-emotional climate in labor collectives: Factors, problems and prospects of development, EurAsian Journal of BioSciences, 13(2), 2027-2032.

Volovskaya, N.M. (2001). Economics and sociology of labor. Moscow: INFRA-M.

Zavyalova, E.K. \& Denisov, A.F. (2008). Features of personnel management in intellectual-intensive companies. Bulletin of Saint Petersburg University. Psychology Series. Sociology. Pedagogy, 4, 381 399.

\section{(9) $\odot \Theta \Theta$}

This work is licensed under a Attribution-NonCommercial-NoDerivatives 4.0 International (CC BY-NC-ND 4.0). 